\title{
DETERMINATION OF THE PHYSICAL AND MECHANICAL PROPERTIES OF WOOD-CEMENT BOARDS PRODUCED WITH Pinus spp AND POZZOLANS WASTE
}

\author{
Adauto José Miranda de Lima ${ }^{1}$, Setsuo Iwakiri², Rosilani Trianoski ${ }^{2, \star}$
}

\begin{abstract}
The objective of this research was to evaluate the physical-mechanical properties of wood-cement boards produced with waste particles of Pinus spp. and sufficient levels of pozzolans to assimilate all $\mathrm{Ca}(\mathrm{OH})_{2}$ produced during the hydration reactions of Portland cement. The pozzolans used were: silica fume, metakaolin, rice husk ash, and calcined ceramic waste. The values of the pozzolans were determined based on the theoretical determination of the $\mathrm{Ca}(\mathrm{OH})_{2}$ content produced by the hydration reactions of Portland cement. The pozzolanic activity index was determined by the modified Chapelle test. The boards were produced through cold compression, and the test specimens were produced and tested for physical and mechanical properties at 28/91 days of curing. The minimum values employed in the Bison ${ }^{\circledR}$ commercial process were used as a reference for the physical-mechanical characterization. The boards produced presented good physical-mechanical properties even with high levels of replacement of cement by pozzolans. These properties were similar to the ones presented by the reference boards, despite the significant reduction in the specific mass of the prototype boards, which demonstrates the technological possibility of the use of these materials in the production of wood-cement boards.
\end{abstract}

Keywords: Wood-cement boards, Pinus spp, silica fume, metakaolin, rice husk ash, calcined ceramic waste.

\section{INTRODUCTION}

Much of the waste generated by the industry has the potential to return to the production chain and generate new materials, including waste from the timber industry. Brazil is the fifth largest agricultural producer in the world. According to the latest survey of the National Forest Information System (SNIF 2016), 267,69 million cubic meters of wood were extracted and about 1,93 million tons of waste were produced in 2015, which could serve as fuel for energy production, through the release of $\mathrm{CO}_{2}$. If not properly disposed of this waste ends up in landfills and undergoes a process of biodegradation, therefore releasing methane, which is up to 72 times more harmful than $\mathrm{CO}_{2}$ for the greenhouse effect (Doudart de La Gree 2014, Cechin 2017).

The waste of other industries also has potential, for instance, those from national steel industries, such as the silica fume (SF), which is a by-product of silicon metal and other silicon alloys manufacture (Sruthi and George 2017), and the red ceramic waste (RCW), which is produced through the calcination of dehydroxylation of kaolinite, illite and montmorillonite clays at temperatures between $500^{\circ} \mathrm{C}$ and $800^{\circ} \mathrm{C}$ and results in amorphous material with pozzolanic properties (Garcia et al. 2015). Rice husk ashes (RHA), a by-product of rice husk burning, are in general disposed inappropriately in the environment. (Tashima et al. 2012).

These materials as well as the metakaolin (MK), generated by the commercial production of the calci- 
nation of kaolinitic clays, are named pozzolans. They have the capacity to react with $\mathrm{Ca}(\mathrm{OH})_{2}$, resulting in stable compounds with binding powers, and can replace, to some levels, the Portland cement in cementitious materials (Souza et al. 2014). Among the materials that can be produced by adding value to this waste, there are the wood-cement boards (Claramunt et al. 2015).

Wood-cement boards present a number of advantages when compared to wood or asbestos cement, such as fire and storm resistance, good acoustic insulation, dimensional stability, resistance to attacks from biodegradable agents, and high resistance in relation to their low weight. Besides, they do not emit toxic waste during their production and do not use asbestos, which is already banned in several countries and in some Brazilian states (Tichi et al. 2016, Hamouda et al. 2015).

Conversely, according to Fan et al. (2012), the remaining $\mathrm{Ca}(\mathrm{OH})_{2}$ in the hydrated cementitious matrix increases the pulp $\mathrm{pH}$ to approximately 12,5 causing the wood swelling, dissolution, and degradation. The $\mathrm{pH}$ increase can remove most of the extractives and dissolve considerable parts of the wood components, especially the hemicellulose. It also provides dimensional changes in the wood-cement composite.

To reduce the alkalinity of the cementitious matrix, some authors recommend the use of pozzolans, such as silica fume, metakaolin (Ribeiro 2016), calcined ceramic waste (Lima et al. 2011), and rice husk ash (Lima and Iwakiri 2011).

For Kulakowski et al. (2009), the $\mathrm{pH}$ reduction in cementitious matrices with partial replacement of cement by pozzolans can be explained by the incorporation of $\mathrm{OH}^{-}$and $\mathrm{Ca}^{2+}$ ions into the $\mathrm{C}-\mathrm{S}-\mathrm{H}$ structure formed during the pozzolanic reactions. The concentration of ions present in the solution of the cementitious matrix pores is altered by the cement hydration time. After a few hours of cement hydration, the solution presents an increase in alkaline bases, $\mathrm{KOH}$, and $\mathrm{NaOH}$, and a decrease in the concentration of $\mathrm{Ca}(\mathrm{OH})_{2}$, which is less soluble. By the addition of pozzolans, the alkalinity of the pore solution is altered according to the chemical composition of the additive used (Baroghel-Bouny et al. 2014).

This reaction, as well as the heat release rate and the resistance development, are slow processes, and they occur according to the expression by Baroghel-Bouny et al. (2014) and Ardanuy et al. (2015), Equation 1 and 2:

$$
\begin{aligned}
& \text { Pozzolan }+\mathrm{Ca}(\mathrm{OH})_{2}+\mathrm{H}_{2} \mathrm{O} \longrightarrow \mathrm{CSH} \\
& 3 \mathrm{Ca}^{++}+2 \mathrm{H}_{2} \mathrm{SiO}_{4}{ }^{2-}+2 \mathrm{OH}^{-}+2 \mathrm{H}_{2} \mathrm{O} \rightarrow \mathrm{Ca}_{3}\left[\mathrm{H}_{2} \mathrm{Si}_{2} \mathrm{O}_{7}\right](\mathrm{OH})_{2} 3 \mathrm{H}_{2} \mathrm{O}
\end{aligned}
$$

The Brazilian ABNT NBR 15895 (2010) and French NFP 18513 (2010) standards present the modified version of the Chapelle method, which is the methodology that has been most used to determine the $\mathrm{Ca}(\mathrm{OH})_{2}$ content fixed by a material with pozzolanic characteristics. The result is expressed in $\mathrm{mg}$ of $\mathrm{CaO}$ or $\mathrm{Ca}(\mathrm{OH})_{2} / \mathrm{g}$ of pozzolan. In Brazil, the material pozzolanicity is acknowledged when the $\mathrm{CaO}$ consumption exceeds 330 $\mathrm{mg} \mathrm{CaO} / \mathrm{g}$ of pozzolan. On stoichiometry, this value corresponds to $436 \mathrm{mg} \mathrm{Ca}(\mathrm{OH})_{2} / \mathrm{g}$ of pozzolan (Macioski 2017).

Thus, the objective of this research was to evaluate the physical and mechanical properties of wood-cement boards produced with waste particles of Pinus spp. and four types of pozzolans: silica fume, metakaolin, rice husk ash, and calcined ceramic waste.

\section{MATERIAL AND METHODS}

Waste particles of Pinus spp were collected at a logging company located in the municipality of Almirante Tamandaré (state of Paraná, Brazil). Silica fume (SF), commercially named Silmix ${ }^{\circledR}$, and metakaolin (MK), 
commercially Metacaulim $\mathrm{HP}^{\circledR}$, were purchased from a building materials store in the city of Curitiba (state of Paraná, Brazil). Rice husk ash (RHA) came from the city of Jaraguá (state of Santa Catarina, Brazil), and calcined ceramic waste $(\mathrm{CCW})$ was provided by pottery located in the city of Curitiba.

The Portland cement used in this research was the CPV-ARI, purchased in a market of Curitiba. It was also used: the accelerating effect; The calcium chloride bihydrate $\left(\mathrm{CaCl}_{2} 2 \mathrm{H}_{2} \mathrm{O}\right), \mathrm{pH}=8,50$ to accelerate the process, was produced by the IPC do Nordeste Ltda, located in the city of Camaçari (state of Bahia, Brazil); and the third-generation superplasticizer additive - polycarboxylate base - $\mathrm{MC}$ Powerflow 1095, $\mathrm{pH}=6,75$ manufactured and distributed by the MC - Bauchemie Brasil Indústria e Comércio Ltda.

The waste particles of Pinus spp. used in this research presented a total extractive content of 2,43\% and a $\mathrm{pH}$ of 5,07 . Tests to determine these values were conducted according to the TAPPI T $204 \mathrm{~cm}(2017)$ and TAPPI T 252 om (2016) standards.

The definition of the pozzolanic activity index (PAI) of the pozzolans was done based on the modified Chapelle method, in accordance with the ABNT NBR 15895 (2010) and NFP 18513 (2010) standards. After determining the $\mathrm{Ca}(\mathrm{OH})_{2}$ content fixed by the pozzolans, the minimum amounts of SF, MK, RHA, and CCW sufficient and necessary to assimilate all $\mathrm{Ca}(\mathrm{OH})_{2}$ of the hydrated cement were determined.

According to previous studies by Lima et al. (2011), the boards were produced with cement-wood composites with a cement/wood ratio equal to $1 / 13,33$ in order to maximize the effect of cement replacements, and a water/cement ratio equal to 0,40 . The dosage of the materials was performed for a nominal density of the boards of $1,50 \mathrm{~g} / \mathrm{cm}^{3}$. To correct water content, the fiber saturation point (FSP) of $30 \%$ was considered. The waste particles of Pinus spp. were initially pretreated in cold water extraction for 24 hours. The cement-setting accelerator effect content used was $4,5 \%$ in relation to the composite cement mass and the superplasticizer additive content. In composites with partial replacements of cement by pozzolans, it varied according to the content and type of pozzolan used, so that the composite had a constant consistency of $250 \pm 5 \mathrm{~mm}$. This consistency was adopted as the standard since it was determined for the reference composite, which was produced with no cement replacement.

The boards were produced through cold compression, with specific pressure of $40 \mathrm{kgf} / \mathrm{cm}^{2}$, and their dimensions were $270 \mathrm{~mm} \times 220 \mathrm{~mm}$ x 12,5 $\mathrm{mm}$. They were superimposed in groups of 4 boards and kept nailed for 24 hours (initial curing) (Figure 1b and Figure 1c). For the compression molding, the universal test machine Emic (Instron Brasil), model DL 30000, was used. After this period, demolding was performed (Figure 1d) by removing the fixation nails, and the boards were stored in a humidity chamber at the temperature of $23 \pm 2^{\circ} \mathrm{C}$ and relative humidity of $95 \%$ or higher. After curing for 28 and 91 days, the boards were sawed to produce the test specimens; the dimensions were in accordance with the ASTM D 1037 (2012) standard.

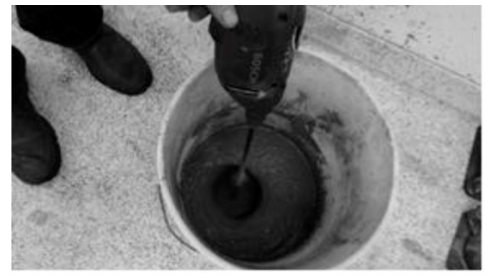

(a)

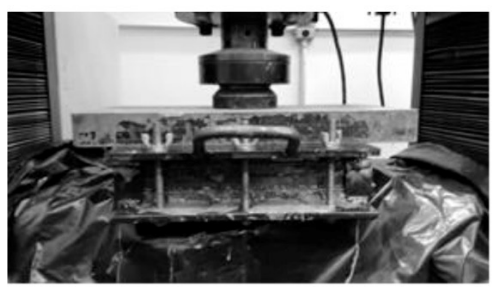

(c)

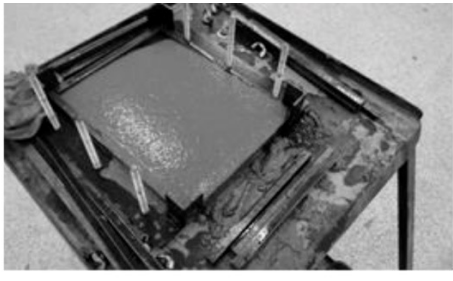

(b)

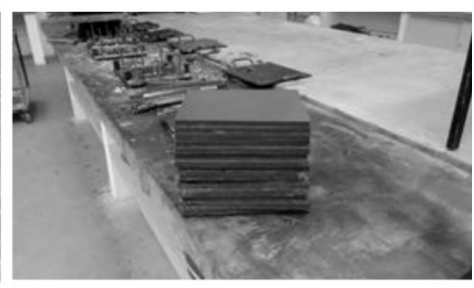

(d)

Figure 1: Prototype boards production. (a) Mixing of components (b) Placing in the forms (c) Compression and stapling (d) Deforms. 
Tests to determine the compressive strength (CS), internal bond (IB), modulus of rupture (MOR), and modulus of elasticity (MOE) in static bending were performed according to the ASTM D 1037 (2012) standard, whereas tests to determine thickness swelling (TS) after 24 hours were conducted according to the European EN 317 (1993) standard. Dry density (DD) was determined according to the ABNT NBR 9778 (2005) and ASTM C 642 (2002) standards. The mechanical properties of the boards were determined in a universal test machine Emic (Instron Brasil), model DL 10000. The results were compared to the reference values of the Bison $^{\circledR}$ industrial production process (NCL IND 2020).

They were statistically analyzed with the aid of ANOVA, and the averages of the values observed were compared via Tukey test at a confidence level of $95 \%$.

\section{RESULTS AND DISCUSSION}

$\mathrm{Ca}(\mathrm{OH})_{2}$ content from the Portland cement CPV-ARI used in this research and determined by stoichiometry resulted in $27,39 \%$.

Based on the pozzolan analyses by the Chapelle method, the fixed $\mathrm{Ca}(\mathrm{OH})$, contents were determined, as presented in Table 1. According to the Chapelle test values, the minimum and sufficient pozzolan contents were determined for the sufficient minimum amount to assimilate the $27,39 \%$ of $\mathrm{Ca}(\mathrm{OH})_{2}$, produced in the cement hydration. The values obtained were: $29,45 \%$ for SF replacement; $29,16 \%$ for MK; $31,76 \%$ for RHA; and $47,63 \%$ for CCW. In order to facilitate the research, rounded figures were adopted (30\% for SF and MK; $35 \%$ for RHA; and $50 \%$ for $\mathrm{CCW}$ ).

Table 1: $\mathrm{Ca}(\mathrm{OH})_{2}$ contents fixed by pozzolans.

\begin{tabular}{|c|c|c|c|}
\hline Pozzolan & $\begin{array}{c}\mathbf{I}_{\mathbf{C a}(\mathbf{O H}) \mathbf{2}} \\
\left(\mathbf{m g ~ C a}(\mathbf{O H})_{2} / \mathbf{g} \text { pozzolan }\right)\end{array}$ & $\begin{array}{c}\mathbf{C V} \\
(\mathbf{\%})\end{array}$ & $\begin{array}{c}\text { Error } \\
(\mathbf{\%})\end{array}$ \\
\hline SF & $656,02^{\mathrm{A}}$ & 0,33 & 1,24 \\
\hline MK & $665,34^{\mathrm{A}}$ & 0,43 & 1,65 \\
\hline RHA & $588,63^{\mathrm{B}}$ & 1,34 & 4,55 \\
\hline CCW & $301,13^{\mathrm{C}}$ & 2,86 & 4,97 \\
\hline
\end{tabular}

Different letters in the $\mathrm{I}_{\mathrm{Ca}(\mathrm{OH}) 2}$ column indicate statistical differences among the averages at confidence level of 95\%; Averages were obtained through 3 replicates; SF: Silica fume; MK: Metakaolin; RHA: rice husk ash; CCW: Calcined ceramic waste; CV: Coefficient of variation; Error: Standard error.

Before the composites production process, an analysis of the superplasticizer additive consumption was conducted to keep the composite consistency at $250 \pm 5 \mathrm{~mm}$. This value was determined in the flow table, in accordance with the ABNT NBR 7215 (2009) standard. The required additive content was 1\% in relation to the sum of the cement and pozzolans used amount.

Table 2 shows the dry density of the boards produced. Values obtained for all boards in the dry state were higher than $1 \mathrm{~g} / \mathrm{cm}^{3}$, as recommended by the BSI BS EN 323 (1993) standard. Densities of the boards produced with Portland cement replacements were significantly lower than those of the reference boards, with reductions of around 7,01\% (MK30) to $15,92 \%$ (SF30). 
Table 2: Dry density of boards.

\begin{tabular}{|c|c|c|c|c|}
\hline Board & $\begin{array}{l}\text { DD28d } \\
\left(\mathrm{g} / \mathrm{cm}^{3}\right)\end{array}$ & $\begin{array}{l}\text { CV } \\
(\%)\end{array}$ & $\begin{array}{l}\text { Error } \\
\left(\mathrm{g} / \mathrm{cm}^{3}\right)\end{array}$ & Variation of DD (\%) \\
\hline REF & $1,57 \mathrm{~A}$ & 0,57 & 0,004 & - \\
\hline SF30 & $1,32 \mathrm{E}$ & 0,58 & 0,004 & $-15,92 \%$ \\
\hline MK30 & $1,46 \mathrm{~B}$ & 0,72 & 0,005 & $-7,01 \%$ \\
\hline RHA35 & $1,40 \mathrm{D}$ & 0,52 & 0,004 & $-10,83 \%$ \\
\hline CCW50 & $1,44 \mathrm{C}$ & 0,86 & 0,006 & $-8,28 \%$ \\
\hline
\end{tabular}

Different letters indicate statistical differences among averages at confidence level of 95\%; Averages were obtained through 4 replicates; SF: Silica Fume; MK: Metakaolin; RHA: Rice husk ash; CCW: Calcined ceramic waste; DD: Dry density; CV: Coefficient of variation;

Error: Standard error.

Table 3 shows the board thickness swelling after 24 hours of water saturation. As can be seen, all boards presented very low values and no significant differences among them, at both 28 and 91 days of cure. The ST values were $79 \%$ lower than those determined for composites produced with $P$. taeda particles, 73,16\% lower than those produced with $P$. maximinoi, $72,47 \%$ lower than those produced with $P$. tecunumanii, $60 \%$ lower than those produced with $P$. oocarpa and 75,63\% lower than those produced with $P$. caribaea, as presented in Iwakiri et al. (2017). These results, for all panels, were lower than the limit value, which is $1,8 \%$, indicated by the Bison process (NCL IND 2020), and also lower than the 1,5\%, maximum value established in EN 317 (1993).

Table 3: Thickness swelling (TS) variation after 24 hours of saturation.

\begin{tabular}{|l|l|l|l|l|l|l|}
\hline Board & $\begin{array}{l}\text { TS28d } \\
\mathbf{( \% )}\end{array}$ & $\begin{array}{l}\text { CV } \\
\mathbf{( \% )}\end{array}$ & $\begin{array}{l}\text { Error } \\
\mathbf{( \% )}\end{array}$ & $\begin{array}{l}\text { TS91d } \\
(\mathbf{\%})\end{array}$ & $\begin{array}{l}\text { CV } \\
\mathbf{( \% )}\end{array}$ & $\begin{array}{l}\text { Error } \\
(\mathbf{\%})\end{array}$ \\
\hline REF & $0,20 \mathrm{~A}$ & 22,61 & 0,022 & $0,21 \mathrm{~A}$ & 23,66 & 0,024 \\
\hline SF30 & $0,22 \mathrm{~A}$ & 25,79 & 0,028 & $0,21 \mathrm{~A}$ & 27,12 & 0,029 \\
\hline MK30 & $0,21 \mathrm{~A}$ & 30,72 & 0,033 & $0,21 \mathrm{~A}$ & 24,10 & 0,026 \\
\hline RHA35 & $0,23 \mathrm{~A}$ & 20,05 & 0,023 & $0,20 \mathrm{~A}$ & 7,40 & 0,007 \\
\hline CCW50 & $0,19 \mathrm{~A}$ & 28,33 & 0,027 & $0,23 \mathrm{~A}$ & 20,77 & 0,024 \\
\hline
\end{tabular}

Different letters indicate statistical differences among averages at confidence level of 95\%; Averages were obtained through 4 replicates; SF: Silica Fume; MK: Metakaolin; RHA: Rice husk ash; CCW: Calcined ceramic waste; TS: Thickness swelling; CV: Coefficient of variation; Error: Standard error.

By analyzing the values shown in Table 4, it can be concluded that the boards produced with the replacement of Portland cement by pozzolans presented lower results compared to those determined for the reference boards (34,73 $\mathrm{MPa}$ at 28 days and $42,78 \mathrm{MPa}$ at 91 days of curing). This phenomenon was not expected, since pozzolans should assimilate all $\mathrm{Ca}(\mathrm{OH})_{2}$ from the cementitious matrices, transform it into C-S-H and keep the resistance values at the same levels as the reference boards, especially at 91 days of curing. Even so, the determined CS values are well above the 18,13 MPa found by Matoski et al. (2013) or 10,37 MPa, determined by Bertolini et al. (2014), and higher than those determined by Garcez et al. (2016), which presented CS values between 4,16 MPa to 7,35 MPa for composites produced with P. elliotti. 
Table 4: Compressive strength (CS) variation of the boards.

\begin{tabular}{|l|l|l|l|l|l|l|}
\hline Board & $\begin{array}{l}\text { CS28d } \\
\text { (MPa) }\end{array}$ & $\begin{array}{l}\text { CV } \\
\text { (\%) }\end{array}$ & $\begin{array}{l}\text { Error } \\
\text { (MPa) }\end{array}$ & $\begin{array}{l}\text { CS91d } \\
\text { (MPa) }\end{array}$ & $\begin{array}{l}\text { CV } \\
(\%)\end{array}$ & $\begin{array}{l}\text { Error } \\
\text { (MPa) }\end{array}$ \\
\hline REF & $34,73 \mathrm{~B}$ & 1,57 & 0,27 & $42,78 \mathrm{~A}$ & 15,75 & 3,01 \\
\hline SF30 & $26,77 \mathrm{D}$ & 13,22 & 1,25 & $31,05 \mathrm{BC}$ & 11,52 & 1,26 \\
\hline MK30 & $22,33 \mathrm{E}$ & 10,97 & 0,87 & $28,04 \mathrm{CD}$ & 7,49 & 0,74 \\
\hline RHA35 & $29,57 \mathrm{CD}$ & 14,81 & 1,55 & $34,13 \mathrm{~B}$ & 14,09 & 1,70 \\
\hline CCW50 & $27,19 \mathrm{CD}$ & 10,57 & 1,02 & $34,74 \mathrm{~B}$ & 17,46 & 2,14 \\
\hline
\end{tabular}

Different letters indicate statistical differences among averages at confidence level of 95\%; Averages were obtained through 4 replicates; SF: Silica fume; MK: Metakaolin; RHA: Rice husk ash; CCW: Calcined ceramic residue; CS: Compressive strength; CV: Coefficient of variation; Error: Standard error.

Table 5 show the values established for the perpendicular tensile strength (internal bond - IB) of the prototype boards.

Table 5: Internal bond (IB) variation of the boards.

\begin{tabular}{|l|l|l|l|l|l|l|}
\hline Board & $\begin{array}{c}\text { IB28d } \\
\text { (MPa) }\end{array}$ & $\begin{array}{l}\text { CV } \\
(\mathbf{\%})\end{array}$ & $\begin{array}{l}\text { Error } \\
\text { (MPa) }\end{array}$ & $\begin{array}{l}\text { IB91d } \\
\text { (MPa) }\end{array}$ & $\begin{array}{l}\text { CV } \\
\text { (\%) }\end{array}$ & $\begin{array}{l}\text { Error } \\
\text { (MPa) }\end{array}$ \\
\hline REF & $1,09 \mathrm{ABCDE}$ & 12,91 & 0,06 & $1,17 \mathrm{ABC}$ & $\mathbf{1 2 , 6 1}$ & 0,06 \\
\hline SF30 & $1,01 \mathrm{CDE}$ & 14,78 & 0,06 & $1,14 \mathrm{ABCD}$ & $\mathbf{1 5 , 3 6}$ & 0,07 \\
\hline MK30 & $1,07 \mathrm{BCDE}$ & 10,78 & 0,05 & $1,26 \mathrm{~A}$ & 5,58 & 0,03 \\
\hline RHA35 & $0,97 \mathrm{DE}$ & 3,35 & 0,01 & $1,24 \mathrm{AB}$ & 21,15 & 0,11 \\
\hline CCW50 & $0,95 \mathrm{E}$ & 19,44 & 0,08 & $1,13 \mathrm{ABCDE}$ & $\mathbf{1 5 , 3 2}$ & 0,07 \\
\hline
\end{tabular}

Different letters indicate statistical differences among averages at confidence level of $95 \%$; Averages were obtained through 8 repetitions; SF: Silica fume; MK: Metakaolin; RHA: Rice husk ash; CCW: Calcined ceramic waste; IB: Internal bond; CV: Coefficient of variation; Error: Standard error.

The IB values obtained for all boards are above the value of $0,40 \mathrm{MPa}$ indicated by the Bison ${ }^{\circledR}$ process (NCL IND 2020) and are also higher than the minimum value indicated in EN 319 (1993), which is 0,41 MPa. The values determined in this research are similar to those determined by Azambuja et al. (2017), who found IB values of $0,96 \mathrm{MPa}$ for similar composites without the addition of pozzolans and higher values than those determined by Iwaikiri et al. (2017), who researched composites with 5 species of Pinus, finding IB values between $0,41 \mathrm{MPa}$ and $0,85 \mathrm{MPa}$.

This result demonstrates that the levels of replacement of cement by pozzolans did not reduce the internal bond values of the boards, instead, the MK30 and RHA35 panels showed better performance than the REF panels at 91 days of curing. This can be explained by the pozzolanic reactions that transformed the excess of $\mathrm{Ca}(\mathrm{OH})_{2}$ of the cementitious matrix into C-S-H.

Regarding the values of modulus of rupture (MOR) in static bending (Table 6), none of the boards reached the reference minimum resistance value of $9,0 \mathrm{MPa}$ indicated by the Bison ${ }^{\circledR}$ process (NCL IND 2020) and the EN 310 (1993), which may be a consequence of the increased fragility of the boards, even with regards to those from the reference, due to the high levels of binding agents used. Significant differences between the values determined for reference boards and boards produced with pozzolans may be noticed on tests after 91 days of curing. Moreover, it can be verified that the MOR growth between 28 and 91 days of curing was much more noticeable for the reference boards than for those produced with pozzolans. This outcome was not expected, since the pozzolanic reactions should be completed and all $\mathrm{Ca}(\mathrm{OH})_{2}$ from the cement should be transformed into C-S-H at 91 days of curing. The determined MOR values are similar to those determined by Iwakiri et al. (2017), who researched composites without replacing cement with pozzolans and with five different Pinus species and found MOR values between 3,90 MPa to 5,59 MPa. 
Table 6: Modulus of resistance (MOR) in static bending variation.

\begin{tabular}{|l|l|l|l|l|l|l|}
\hline Board & $\begin{array}{l}\text { MOR28d } \\
\text { (MPa) }\end{array}$ & $\begin{array}{l}\text { CV } \\
\text { (\%) }\end{array}$ & $\begin{array}{l}\text { Error } \\
\text { (MPa) }\end{array}$ & $\begin{array}{l}\text { MOR91d } \\
\text { (MPa) }\end{array}$ & $\begin{array}{l}\text { CV } \\
\text { (\%) }\end{array}$ & $\begin{array}{l}\text { Error } \\
\text { (MPa) }\end{array}$ \\
\hline REF & $5,69 \mathrm{BCD}$ & 6,48 & 0,18 & $7,47 \mathrm{~A}$ & 16,74 & 0,72 \\
\hline SF30 & $4,25 \mathrm{G}$ & 14,48 & 0,31 & $4,40 \mathrm{FG}$ & 8,76 & 0,19 \\
\hline MK30 & $4,88 \mathrm{EFG}$ & 5,92 & 0,14 & $5,96 \mathrm{BC}$ & 9,26 & 0,28 \\
\hline RHA35 & $5,26 \mathrm{CDE}$ & 9,18 & 0,24 & $6,08 \mathrm{~B}$ & 9,49 & 0,29 \\
\hline CCW50 & $5,01 \mathrm{DEFG}$ & 1,13 & 0,03 & $5,13 \mathrm{DEF}$ & 10,96 & 0,28 \\
\hline
\end{tabular}

Different letters indicate statistical differences among averages at confidence level of $95 \%$; Averages were obtained through 8 repetitions; SF: Silica fume; MK: Metakaolin; RHA: Rice husk ash; CCW: Calcined ceramic waste; MOR: Modulus of resistance in static bending; CV: Coefficient of variation; Error: Standard error.

Table 7 shows the modulus of elasticity (MOE) values for the boards produced. All values are above the minimum resistance value of $3 \mathrm{GPa}$ indicated by the Bison ${ }^{\circledR}$ process (NCL IND 2020) and the EN 310 (1993), which is 4,5 GPa. The values of MOE determined in this research are between 3 and 4 times higher than those determined by Iwakiri et al. (2017), which ranged from 1,94 GPa to 3,30 GPa. This can also be explained by the high cement/wood ratio used in the production of the prototype panels.

At 28 days of curing, no significant differences were observed between the reference boards and those with pozzolans, except for the boards produced with $50 \%$ of CCW. At 91 days of curing, the MOE evolution for the boards produced with pozzolans was lower than the evolution observed for the reference boards, which provides significant statistical differences within the prototypes at this age.

Table 7: Modulus of elasticity (MOE) in static bending variation.

\begin{tabular}{|l|l|l|l|l|l|l|}
\hline Board & $\begin{array}{l}\text { MOE28d } \\
(\mathbf{G P a})\end{array}$ & $\begin{array}{l}\text { CV } \\
(\mathbf{\%})\end{array}$ & $\begin{array}{l}\text { Error } \\
(\mathbf{G P a})\end{array}$ & $\begin{array}{l}\text { MOE91d } \\
(\mathbf{G P a})\end{array}$ & $\begin{array}{l}\text { CV } \\
(\mathbf{\%})\end{array}$ & $\begin{array}{l}\text { Error } \\
(\mathbf{G P a})\end{array}$ \\
\hline REF & $11,19 \mathrm{BC}$ & 11,15 & 0,62 & $16,20 \mathrm{~A}$ & 19,65 & 1,59 \\
\hline SF30 & $9,47 \mathrm{CD}$ & 19,92 & 0,94 & $9,96 \mathrm{CD}$ & 9,27 & 0,46 \\
\hline MK30 & $10,34 \mathrm{CD}$ & 9,70 & 0,50 & $12,35 \mathrm{~B}$ & 14,13 & 0,87 \\
\hline RHA35 & $9,89 \mathrm{CD}$ & 5,66 & 0,28 & $10,35 \mathrm{CD}$ & 6,99 & 0,36 \\
\hline CCW50 & $8,39 \mathrm{D}$ & 8,07 & 0,34 & $9,69 \mathrm{CD}$ & 5,57 & 0,27 \\
\hline
\end{tabular}

Different letters indicate statistical differences among averages at confidence level of 95\%; Averages were obtained through 8 repetitions; SF: Silica fume; MK: Metakaolin; RHA: Rice husk ash; CCW: Calcined ceramic waste; MOE: Modulus of elasticity; CV: Coefficient of variation; Error: Standard error.

\section{CONCLUSIONS}

The waste wood of Pinus spp. showed good performance as a lignocellulosic aggregate for the production of wood-cement boards, with or without the use of pozzolans.

Based on the PAI determination by the modified Chapelle method, silica fume (SF), metakaolin (MK), and rice husk ashes (RHA) present high levels of pozzolanic activity and can be used on partial replacement of Portland cement for the production of boards. The calcined ceramic waste (CCW) presented a pozzolanic activity index below the minimum value recommended being used as a cement replacement. Thus, high levels of replacement are necessary to assimilate the $\mathrm{Ca}(\mathrm{OH})_{2}$ produced in the Portland cement hydration.

The boards produced with pozzolans presented decreased dry density (DD) values and low thickness swelling (TS) values. The internal bond (IB) values determined by the boards produced with pozzolans showed no difference compared to the values determined by the reference boards, and they were higher than the reference values for commercial boards.

Conversely, they decreased in compressive strength (CS) at both 28 and 91 days of curing, in comparison to the values determined for the reference boards. It also occurred for the modulus of resistance (MOR) in 
static bending and the modulus of elasticity (MOE), but despite this decrease in values in these determined characteristics, the values of CS, MOR and MOE are comparable to the materials produced by other researchers cited in the work and are, in most cases, above the minimum values recommended by the references used, Bison ${ }^{\circledR}$ process (NCL IND 2020) and the EN 310 (1993), which indicates that the replacement of Portland cement by the studied pozzolans can be recommended, mainly due to the environmental gains related to the manufacture of Portland cement.

\section{ACKNOWLEDGEMENTS}

The authors thank the Nucleus of Technological Research (NPT) of the Federal University of Technology Paraná for the support in the execution of the mechanical characterization tests of the boards.

\section{REFERENCES}

ASTM. 2013. Standard test method for density, absorption and voids in hardened concrete. ASTM C 642. 2013. West Conshohocken, USA.

ASTM. 2012. Standard test methods for evaluating properties of wood-base fiber and particle panel materials. ASTM D 1037. 2012. West Conshohocken, USA.

ABNT NBR. 2010. Materiais pozolânicos - Determinação do teor de hidróxido de cálcio fixado - Método Chapelle modificado. ABNT NBR 15895. 2010. Rio de Janeiro.

ABNT NBR. 2009. Argamassa e concreto endurecidos: Determinação da absorção de água, índice de vazios e massa específica. ABNT NBR 9778. 2009. Rio de Janeiro.

ABNT NBR. 2009. Minérios de ferro como insumo para alto-forno - Determinação da redutibilidade pelo índice do grau de redução final. ABNT NBR 7215. 2009. Rio de Janeiro.

Ardanuy, A.M.; Claramunt, J.; Toledo-Filho, R.D. 2015. Cellulosic fiber reinforced cement-based composites: A review of recent research. Construction and Building Materials 79 (15): 115-128. https://doi.org/10.1016/j.conbuildmat.2015.01.035.

Azambuja, R.A.; Castro, V.G.; Villas Bôas, B.T.; Parchen, C.F.A.; Iwakiri, S. 2017. Particle size and lime addiction on properties of wood-cement composites produced by the method of densification by vibro compaction. Ciência Rural 47 (7): e20140250. https://doi.org/10.1590/0103-8478cr20140250.

Baroghel-Bouny, V.; Capra, B.; Laurens, S. 2014. Durabilidade das armaduras e do concreto de cobrimento. Durabilidade do Concreto. São Paulo: Jean-Pierre Olliver e Angélique Vichot, p. 255-326.

Bertolini, M.S.; Campos, C.I.; Souza, A.M.; Panzera, T.H.; Christoforo, A.L.; Lahr, F.A.R. 2014. Wood-cement composites from wastes of Pinus spp. Wood: Effect of particles treatment. International Journal of Composite Materials 4 (2): 146-149. https://doi.org/10.5923/j.cmaterials.20140402.14

BSI BS EN. 1993. Wood-based panels. Determination of density. BSI BS EN 323. 1993. London.

Cechin, L. 2017. Análise da viabilidade de produção de painéis de cimento reforçados com biomassa vegetal e escória de alto-forno. Masters's thesis, Universidade Tecnológica Federal do Paraná, Curitiba.

Claramunt, J.; Ardanuy, M.; Fernandez-Carrasco, L.J. 2015. Wet/dry cycling durability of cement mortar composites reinforced with micro and nanoscale cellulose pulps. BioResources 10 (2): 3045-3055. https://doi.org/10.15376/biores.10.2.3045-3055.

Doudart de la Gree, G.C.H.; Yu, Q.L.; Bouwers, H.I.J. 2014. Wood-wool cement board: Utilization of 
a porous binder. In: $14^{\text {th }}$ International Inorganic-bonded Fiber Composites Conference. Vietnan. p. 177- 186.

EN.1993. Wood Based Panel - Determination of modulus of elasticity in bending and of bending strength. EN 310.1993. London.

EN.1993. Particleboards and fiberboards - Determination of swelling in thickness after immersion in water. EN 317.1993. London.

EN.1993. Wood Based Panel - Determination of tensile strength perpendicular to the plane of the board. EN 319.1993. London.

Fan, M.; Ndikontar, M.K.; Zhou, X.; Ngamveng, J.N. 2012. Cement-bonded composites made from tropical woods: Compability of wood and cement. Construction and Building Materials 36: 135-140. https://doi.org/10.1016/j.conbuildmat.2012.04.089.

Garcez, M.R.; Garcez, E.O.; Machado, A.O.; Gatto, D.A. 2016. Cement-wood composites: effects of wood species, particle treatments and mix proportion. International Journal of Composite Materials 6 (1): 1-8. https://doi.org/10.5923/j.cmaterials.20160601.01

Garcia, E.; Cabral Júnior, M.; Quarcioni, V.A.; Chotoli, F.F. 2015. Resíduo de cerâmica vermelha (RCV): uma alternativa como material pozolânico. Cerâmica Industrial 19 (4): 31- 38. https://ceramicaindustrial.org.br/article/587657577f8c9d6e028b4809/pdf/ci-19-4-587657577f8c9d6e028b4809.pdf

Hamouda, T.; Seyam, A.F.M.; Peters, K. 2015. Evaluation of the integrity of 3D orthogonal woven composites with embedded polymer optical fibers. Composites Part. B: Engineering 78: 79-85. https://doi.org/10.1016/j.compositesb.2015.03.092.

Iwakiri, S.; Trianoski, R.; Fonte A.P.N.; Cezimbra, D.J.; Fomin, I.M.; Molleken, R. 2017. Potential use of tropical pine species for woods cement panel production. Scientia Forestalis 45 (113): 151-159. https://dx.doi.org/10.18671/scifor.v45n113.15.

Kulakowski, M.P.; Pereira, F.M.; Molin, D.C.C.D. 2009. Carbonation-induced reinforcement corrosion in silica fume concrete. Construction and Building Materials 23(3): 1189-1195. https://doi.org/10.1016/j.conbuildmat.2008.08.005.

Lima, A.J.M.; Iwakiri, S. 2011. Produtos alternativos na produção de blocos para alvenaria estrutural. Floresta e Ambiente 18(3): 310-323. http://dx.doi.org/10.4322/floram.2011.051.

Lima, A.J.M.; Iwakiri, S.; Lomelí-Ramírez, M.G. 2011. Utilização de resíduos de Pinus spp., metacaulim de alta reatividade e resíduo de cerâmica calcinada em compósitos cimento-madeira. Madera y Bosques 17(2): 47-65.

Macioski, G. 2017. Estudo da álcali-ativação de pó de blocos cerâmicos com cal hidratada. Master's thesis, Universidade Tecnológica Federal do Paraná, Curitiba.

Matoski, A.; Hara, M.M.; Iwakiri, S.; Casali, J.M. 2013. Influence of accelerating admixtures in wood-cement panels: characteristics and properties. Acta Scientiarum Technology 35(4): 655-660. https://doi.org/10.4025/actascitechnol.v35i4.11261.

NCL IND. 2020. Bison Panel - Cement bonded particle board. NCL INDUSTRIES LIMITED. https://bisonpanel.com/about-us/about-bison-panel/why-bison-panel.

NFP. 2010. Addition pour béton hydraulique - Métakaolin - Spécifications et critères de conformité - Métakaolin, addition pouzzolanique pour bétons. NFP 18513. 2010. St. Denis, France.

Ribeiro, U.G. 2016. Desempenho térmico, acústico e mecânico de compósitos cimentícios produzidos com resíduos da indústria madeireira de Porto Velho. Master's thesis, Universidade Federal do Amazonas, Manaus.

SNIF. 2016. Produção Florestal. http://www.florestal.gov.br. 
Souza, F.B.; Ramos Netto, A.L.; Silva, D.S.; Silva, B.V. 2014. Análise comparativa das propriedades de concretos convencionais com substituição parcial do cimento Portland por cinza de casca de arroz. Iniciação Cientifica 12(1): 5-18.

Sruthi, V.; George, E. H. 2017. A review on silica fume - An additive in concrete. International Journal of Innovative Research in Science 3(3): 1-15.

TAPPI. 2017. CM: Solvent extractives of wood and pulp. TAPPI T 204. 2017. Atlanta.

TAPPI. 2016. OM: $\mathrm{pH}$ and electrical conductivity on hot water extracts of pulp, paper and paperboard. TAPPI T 252. 2016. Atlanta.

Tashima, M.M.; Fioriti, C.F.; Akazaki, J.L.; Bernarbeu, J.P.; Sousa, L.C.; Melges, J.L. P. 2012. Cinza de casca de arroz (CCA) altamente reativa: método de produção e atividade pozolânica. Ambiente Construido 12(2): 151-163. http://hdl.handle.net/10251/56851.

Tichi, A.H.; Bazyar, B.; Khademieslan, H.; Rangavar, H.; Taleipour, M. 2016. The effect of nano-wollastonite on biological, mechanical, physical and microstructural properties of the composite made of wood-cement fiber. Journal of Fundamental and Applied Sciences 8(3): 1466-1479. http://dx.doi.org/10.4067/S0718-221X2015005000072. 